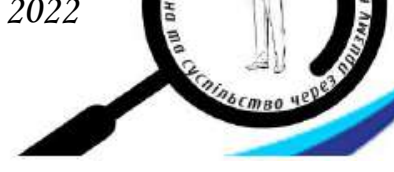

УДК 37.013; 371

https://doi.org/10.52058/2786-5274-2022-1(3)-265-274

Куриш Наталія Костянтинівна кандидат педагогічних наук, заступник директора $з$ науково-навчальної роботи, Інститут післядипломної педагогічної освіти Чернівецької області, вул. І.Франка, 20, м. Чернівці, 58000, тел.: (0372) 52-73-36, https://orcid.org/0000-0001-5864-8502

\title{
ОНОВЛЕНЕ ОСВІТНЕ СЕРЕДОВИЩЕ - ОДНА ІЗ ВАЖЛИВИХ СКЛАДОВИХ РЕАЛІЗАЦІї КОНЦЕПЦІї НОВОЇ УКРАЇНСЬКОЇ ШКОЛИ
}

Анотація. У статті визначено ключові підходи до модернізації освітнього процесу закладу загальної середньої освіти в умовах реалізації Нової української школи, що полягає, перш за все, в оновленні освітнього середовища.

Проведено аналіз нормативно-правової бази та поглядів науковців щодо теоретичних, практичних i соціальних аспектів формування сучасного освітнього середовища, як важливої складової освітньої реформи та визначення ключових понять: «середовище», «освітне середовище», «педагогіка середовища», «освітній простір», «Нова українська школа».

Автором визначено ключові якості сучасного освітнього середовища, які забезпечують реалізацію інноваційних підходів в освіті: цілісність, єдність і впорядкованість предметно-просторового середовища та візуального сприйняття; багатофункціональність, гнучкість та мобільність; вікова відповідність; персоналізованість, наявність особистого простору; свобода, відкритість сприйняття, креативність; практичність та ергономіцність; гармонійність та збалансованість; соціалізація та співпраця.

Обгрунтовано основні напрями оновлення освітнього середовища закладу загальної середньої освіти, що забезпечить надання якісних освітніх послуг: зміна ставлення до дитини, матеріально-технічне забезпечення, осучаснення основних складових архітектурно-художнього рішення будівлі, внутрішній дизайн класів та навчальних приміщень.

Розкрито практичну спрямованість модернізованого освітнього простору навчального кабінету Нової української школи, що передбачає використання нових IT-технологій, нових мультимедійних засобів навчання, оновлення обладнання та облаштування вісім навчальних осередків для забезпечення дослідницької діяльності дітей, формування самостійності й організації роботи дітей в парах, у малих групах, а також індивідуально.

Ключові слова: середовище, педагогіка середовища, освітній простір, освітнє середовище, Нова українська школа. 
Kurysh Natalia Konstantinovna Candidate of pedagogical sciences, Deputy Director for Research and Education Institute of Postgraduate Pedagogical Education of Chernivtsi region, 20, Franka St., Chernivtsi, 58000, tel.: (0372) 52-73-36, https://orcid.org/0000-0001-5864-8502

\section{EDUCATIONAL ENVIRONMENT IS RENEWED - ONE OF IMPORTANT CONSTITUENTS OF REALIZATION OF CONCEPTION OF NEW UKRAINIAN SCHOOL}

Abstract. In the article certainly key going near modernization of educational process of establishment of universal middle education in the conditions of realization of New Ukrainian school which consists, foremost, in the update of educational environment. An analysis is conducted normatively legal base and looks of research workers in relation to the theoretical, practical and social aspects of forming of modern educational environment, as an important constituent of educational reform and determination of key concepts: «environment», «educational environment», «pedagogics of environment», «educational space», «New Ukrainian school».

By an author certainly key qualities of modern educational environment, which provide realization of innovative approaches in education: integrity, unity and efficiency, in detail spatial environment and visual perception; multifunctionness, flexibility and mobility; age-old accordance; personalizovanist, presence of the personal space; freedom, openness of perception, kreativnist; practicality and ergonomicnist; harmoniousness and balanced; socialization and collaboration.

Grounded basic directions of update of educational environment of establishment of universal middle education which will provide the grant of highquality educational services: change of attitude toward a child, logistical support, osuchasnennya of basic constituents, architectonically artistic decision of building, internal design of classes and educational apartments.

The practical orientation of the modernized educational space of educational cabinet of New Ukrainian school, which foresees the use of new IT-technologies, new multimedia facilities of studies, update of equipment and oblashtuvannya, eight educational cells for providing of research activity of children, forming of independence, organizations of work of children in pair, is exposed, in small groups, and also individually.

Keywords: environment, pedagogics of environment, educational space, educational environment, New Ukrainian school.

Постановка проблеми. Нова українська школа передбачає зміни не лише у змісті освітніх програм, а в першу чергу - у ключових підходах до освітнього процесу. Шкільна освіта в Україні переходить від повідомлення інформації до розвитку життєвих компетенцій, від одноманітного стандартизованого 
підходу - до дитиноцентризму та особистісної орієнтації, від педагогіки інструктажу та впливу - до педагогіки партнерства. Ці підходи вимагають, перш за все, оновлення освітнього середовища, яке повинно бути гнучке, різнобарвне, створювати різноманітні можливості для різних видів діяльності, викликати радість, стимулювати фантазію, мотивувати до навчання.

Можна зазначити ключові якості сучасного освітнього середовища, які забезпечують реалізацію інноваційних підходів в освіті:

- цілісність, єдність і впорядкованість предметнопросторового середовища та візуального сприйняття;

- багатофункціональність, гнучкість та мобільність;

- вікова віповідність;

- $\quad$ персоналізованість, наявність особистого простору;

- $\quad$ свобода, відкритість сприйняття, креативність;

- $\quad$ практичність та ергономіцність;

- $\quad$ гармонійність та збалансованість;

- $\quad$ соціалізація та співпраця.

Аналіз останніх досліджень і публікацій. Для побудови принципово нового освітнього середовища у закладах освіти України запозичено досвід закордонних країн, які вже багато років організовують шкільне навчання по цьому принципу: Данії, Естонії, Німеччини, Польщі, Швеці, Фінляндії.

Що стосується трактування терміну «середовище» у його найширшому розумінні можна розглядати, як оточення, яке складається із сукупності природних, матеріальних, соціальних чинників, які прямо чи опосередковано впливають на людину. Середовище - це те, що знаходиться між об'єктами, є «посередником» між ними.

В.О. Сухомлинський у циклі бесід, які нам відомі під загальною назвою «Розмова 3 молодим директором», стверджує, що середовище - «це і світ речей, що оточують учня, i вчинки старших, i особистий приклад вчителя, $\mathrm{i}$ загальний моральний тонус життя шкільного колективу (як матеріалізується ідея піклування про людину), чуйність, сердечність». Видатний вчитель звертає увагу на той факт, що «середовище не $\epsilon$ чимось раз назавжди створеним і незмінним», «середовище повинно повсякденно створюватись $\mathrm{i}$ збагачуватись». [1, 190-191].

На думку українського вченого Станіслава Теофіловича Шацького, якого вважають автором поняття «педагогіка середовища», джерело розвитку дитини лежить не тільки у генетичних задатках, а у тому соціальному й економічному середовищі, в якому відбувається ऑii формування i виховання. «Освітнє середовище» за визначенням російського психолога Вітольда Ясвіна це характеристика життя всередині освітнього закладу, система впливів і умов формування особистості, система можливостей для розвитку особистості у соціальному та просторово-предметному оточенні [2]. 
Проведені дослідження дозволяють нам зробити висновок, що освітнє середовище закладу загальної середньої освіти в умовах Нової української школи - це загальний, сукупний, інтегральний, цілісний чинник надання якісних освітніх послуг та розвитку і становлення особистості, що відіграє визначальну роль у модифікації поведінки, яка розгортається як внаслідок запланованих, так і незапланованих умов середовища, сприяє їх особистісному розвитку. Отже, узагальнюючи проаналізовані наукові підходи до тлумачення поняття «освітнє середовище», можемо констатувати, що більшість науковців під освітнім середовищем розуміють багаторівневу систему умов/обставин/чинників/можливостей, яка забезпечує оптимальні параметри освітньої діяльності певного освітнього суб'єкта в усіх аспектах - цільовому, змістовому, процесуальному, результативному, ресурсному.

Враховуючи вищезазначене, поняття освітнього середовища можна розглядати як із позиції суб'єкта, так і з позиції об'єкта навчальної діяльності, а саме:

- освітнє середовище (з позиції суб'єкта) - це система впливів і умов формування особистості, а також можливостей для іiї розвитку, які містяться в соціальному і просторово-предметному оточенні;

- освітнє середовище (з позицій об'єкта) - це сукупність об'єктивних зовнішніх умов, факторів, соціальних об'єктів, необхідних для успішного функціонування освіти, тобто надання якісних освітніх послуг. Воно складається 3 таких структурних компонентів: фізичне оточення, людський фактор, програма навчання.

Метою статті $\epsilon$ проаналізувати особливості сучасного освітнього середовища та визначити його практичну значущість для забезпечення реалізації Концепції Нової української школи.

Виклад основного матеріалу. Реформування української системи освіти відбувається за трьома основними напрямами: оновлення освітнього середовища; забезпечення нового змісту освіти; підготовка педагогічних працівників, які будуть працювати у Новій українській школі.

Що стосується освітнього середовища, аналізуючи із позиції об'єкта, можна зазначити - реформа передбачає не тільки оновлення матеріальнотехнічної бази, а перш за все це зміна ставлення до дитини: повага, увага до неї та прагнення знайти оптимальний спосіб для ії ефективного навчання [3]. Тому для організації ефективного освітнього процесу в умовах Нової української школи необхідно створити безпечне освітнє середовище та врахувати вікові особливості, фізичний, психічний та інтелектуальний розвиток дітей, їх особливі освітні потреби. Особливості безпечного освітнього середовища визначаються у статті 1 Закону України «Про загальну середню освіту», як сукупність умов у закладі освіти, що унеможливлюють заподіяння учасникам освітнього процесу фізичної, майнової та/або моральної шкоди, зокрема внаслідок недотримання вимог санітарних, протипожежних та/або будівельних 
норм і правил, законодавства щодо кібербезпеки, захисту персональних даних, безпеки харчових продуктів та/або надання неякісних послуг 3 харчування, шляхом фізичного та/або психологічного насильства, експлуатації, дискримінації за будь-якою ознакою, приниження честі, гідності, ділової репутації (булінг (цькування), поширення неправдивих відомостей тощо), пропаганди та/або агітації, у тому числі з використанням кіберпростору, а також унеможливлюють вживання на території закладу освіти алкогольних напоїв, тютюнових виробів, наркотичних засобів, психотропних речовин [4].

Відповідно, можна зазначити, що одним із напрямів оновлення освітнього середовища закладу освіти, в умовах сучасних процесів реформування українського суспільства - $\epsilon$ осучаснення основних складових архітектурнохудожнього рішення будівлі, тобто просторово-предметного оточення, що полягає у:

- плануванні та облаштуванні пришкільної ділянки;

- оновленні зовнішнього вигляду будівлі;

- плануванні, меблюванні та обладнанні інтер'єрів.

Для забезпечення цих якостей дизайн освітнього простору повинен мати цілісне композиційно-колористичне рішення, що розробляється як єдина концепція в процесі проєктування.

Слід зазначити, що при розробленні художньої концепції закладу освіти слід враховувати такі загальні рекомендації:

- Рішення фасаду будівлі має враховувати оточення, але шкільна будівля має виділятись в навколишньому середовищі, мати характерний вигляд, який дає зрозуміти, що це саме заклад освіти, а не, скажімо, житловий будинок чи розважальний центр.

- В межах загальної концепції зовнішній вигляд будівлі може бути більш яскравий та виразний, ніж інтер'єр. Будівля в навколишньому просторі є лише фрагментом пейзажу, який має привертати увагу; тим часом інтер'єр - це місце постійного перебування учнів та вчителів. Це місце має бути комфортним для тривалої діяльності, не розпорошувати увагу, не дратувати.

- Групи приміщень, призначені для учнів різного віку, мають відрізнятись за оформленням. Приміщення початкової школи слід робити більш теплими, затишними, створювати можливості як для рухливої діяльності, так і для тихого спілкування та усамітнення. Приміщення для старших учнів мають більш діловий характер, сприяють концентрації, створюють робочий настрій.

- Група основних загальношкільних приміщень - вестибюль, актова зала - $\epsilon$ обличчям школи. Їх оформлення $\epsilon$ найбільш виразним, наочно виражає неповторний образ школи та має відповідати особливостям сприйняття простору, підкреслювати структуру та функцію приміщень, а не руйнувати ії.

- Оформлення інтер'єру школи має стимулювати фантазію учнів, а не підміняти аї фантазією професійного художника-оформлювача. В оформленні школи слід віддавати перевагу творчості учнів - створювати можливості для 
виставок учнівських робіт, виділяти зони для малювання на стінах, надавати можливість учням самостійно оформлювати окремі простори в рамках навчальних проєктів.

- Комунікації (підходи на ділянці, вхід до будівлі, двері, коридори, переходи, сходи тощо) мають сприяти орієнтації у просторі, вони мають бути помітними, можуть бути досить яскравими, але не темними.

Держава та органи місцевого самоврядування активно підтримують заклади освіти щодо оновлення сучасного освітнього середовища та створення комфортних умов для перебування в установах всіх учасників освітнього процесу. Прикладом підтримки держави є створення сучасного простору у Рідківській ЗОШ I-III ст. Чернівецького району, Чернівецької області, будівництво якої відбувалося за програмою «Спроможна школа для кращих результатів» та завершено у 2020 році.

Потужний масштабний проєкт Президента та Уряду України «Велике будівництво» сприяв створенню нового освітнього середовища у 2021 році у наступних закладах загальної середньої освіти Чернівеччини:

- Веренчанської ЗОШ І-ІІІ ступеня;

- Їжівської ЗОШ I - II ступенів;

- Михалківського ліцею;

- Товтрівської ЗОШ I-III ступенів;

- Старокрасношорської ЗОШ I-II ступенів.

Під час проведення реконструкції зазначених закладів оновлюючи дизайн фасадів враховувалися такі аспекти:

- силует та композиція фасаду;

- оздоблювальні матеріали та колористика фасаду;

- рішення окремих елементів фасаду: вхідної групи, вікон тощо;

- декоративні елементи фасаду, зокрема стінописи.

Для забезпечення надання якісних освітніх послуг під час оновлення інтер'єру закладів освіти необхідно враховувати також:

- склад, кількість та параметри секцій, блоків та окремих приміщень/навчальних кабінетів;

- загальне планування будівлі, взаємне розташування приміщень/навчальних кабінетів та зручні зв'язки між ними;

- художнє рішення інтер'єрів, оздоблення та колористика внутрішнього простору будівлі;

- меблювання та обладнання приміщень/навчальних кабінетів.

Аналізуючи освітні середовища закладів та установ освіти можна зауважити, що вони не дають змоги реалізувати всі завдання та ідеї Концепції Нової української школи, не відповідають тим стандартам, які вимагають навчати дітей по новому, використовуючи інтерактивні технології та методи роботи. Адже шкільні будівлі, що зводились у 1930-1980-ті роки за типовими проєктами, виявляються малопридатними для сучасних педагогічних підходів. 


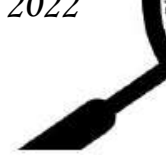

I зовнішній вигляд, і просторова організація, і дизайн інтер'єру таких будівель здебільшого є одноманітними, монотонними, стандартизованими. Типові приміщення таких будівель пристосовані лише до однієї форми роботи, не дозволяють урізноманітнити організацію освітнього процесу.

Типовий, стандартизований простір пригнічує творчість вчителів та учнів, викликає скоріше нудьгу, розчаровує та демотивує. Такий простір потребує оновлення на основі сучасних підходів.

Крім того, зі зміною демографічної ситуації в окремих громадах відчувається невідповідність розміру та структури шкільних будівель актуальним освітнім потребам. В одних випадках будівля школи виявляється завеликою та використовується нераціонально, в інших катастрофічно не вистачає місця.

Тому при розробленні оновлення освітнього середовища закладу, плануванні будь-яких змін в організації шкільної будівлі варто орієнтуватись на укрупнений показник наповнюваності школи - частку загальної площі будівлі, що припадає на одного учня.

У нині чинному ДБН В.2.2-3:2018 «Будинки і споруди. Заклади освіти» укрупнені показники виключено, площу будівлі передбачається встановлювати детальними розрахунками. Такі розрахунки на основі норм чинного ДБН показують результат близько $15 \mathrm{~m}^{2}$ загальної площі шкільної будівлі на одного учня [5]. Цей показник можна брати за орієнтир для попереднього визначення, чи потребує будівля реконструкції з розширенням, чи навпаки є завеликою для освітніх потреб громади.

Плануючи створення сучасного освітнього простору необхідно враховувати, також, вимоги Санітарного регламенту (наказ Міністерства охорони здоров’я України №2205 від 25.09.2020), зокрема:

- адаптація простору в навчальних кабінетах;

- мотивуюче для учнів середовище;

- місця для відпочинку дітей;

- ігрові осередки;

- безпека шкільної території та спортивних майданчиків;

- нове трактування поняття «самообслуговування» [6].

Важливим є зараз сформувати освітнє середовище навчальних кабінетів для забезпечення впровадження нового Державного стандарту базової середньої освіти: підбір меблів та обладнання, що дозволять урізноманітнити діяльність - плановану чи спонтанну, спокійну та рухливу, індивідуальну та в малих чи великих групах. При плануванні внутрішнього дизайну класів та навчальних приміщень, також, необхідно врахувати:

- сучасне оформлення класів повинно відбуватися 3 максимальним використанням стін в освітньому процесі (розміщення декількох дощок та мультимедійних засобів навчання);

- наявність безпечних розеток та проводки для комп'ютерів, електронного робочого місця вчителя, мультимедійної дошки, проєктора; 
- багатофункціональний навчальний простір, максимальна можливість використання приміщень школи для організації різних форм навчання;

- використання меблів-трансформерів та мобільних меблів для різних форм організації навчання [7].

Відповідно до методичних рекомендацій щодо організації освітнього простору Нової української школи, затверджених наказом Міністерства освіти і науки України від 23.03.2018 № 283 організовуючи освітній простір навчального кабінету потрібно передбачити використання нових IT-технологій, нових мультимедійних засобів навчання, оновлення обладнання та облаштування вісім навчальних осередків:

осередок навчально-пізнавальної діяльності 3 партами/столами $\mathrm{i}$ стільцями;

змінні тематичні осередки, в яких розміщуються дошки/фліп-чарти/стенди для діаграм з ключовими ідеями та стратегіями, карти тощо;

осередок для гри, оснащений настільними іграми, інвентарем для рухливих ігор;

осередок художньо-творчої діяльності 3 поличками для зберігання приладдя та стендом для змінної виставки дитячих робіт;

куточок живої природи для проведення дослідів (пророщування зерна, спостереження та догляд за рослинами, акваріум);

осередок відпочинку з килимом для сидіння та гри, стільцями, крісламипуфами, подушками з м'яким покриттям;

дитяча класна бібліотечка;

осередок вчителя, оснащений столом, стільцем, комп'ютером, полицями/ящиками, шафами для зберігання дидактичного матеріалу тощо[8].

Організація навчальних осередків здійснюється для забезпечення дослідницької діяльності дітей, формування самостійності та організації роботи дітей в парах, у малих групах, а також індивідуально. У навчальних осередках можна проводити різні види освітньої діяльності, тому вони мають містити різні навчальні матеріали [9].

Отже, таке освітнє середовище дає можливість зацікавити учнів до різних видів діяльності і сприяє самовизначенню дітей у класі, розвитку їхніх спроможностей та кращій адаптованості до самостійного життя. Різноманіття у навчальних осередках забезпечує можливості школярів здійснювати вибір у класі i, відповідно, приймати самостійні рішення, усвідомлюючи при цьому їх наслідки.

Вільний вибір учнями навчальних матеріалів, робочого місця за столом, де вони бажають працювати та інше, забезпечують ефективну індивідуалізацію навчального процесу враховуючи потреби й інтереси дітей.

При правильній організації освітнього простору в класі: вчитель має змогу вільно спостерігати за діяльністю дітей в усіх осередках діти можуть безпечно переміщуватися, мають місце для зберігання особистих речей. 


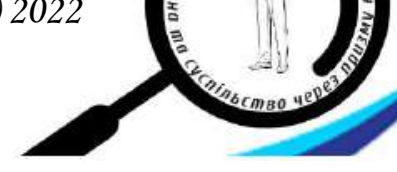

Дуже важливо при побудові нового освітнього простору за стандартами НУШ - це не перестаратися з оформленням. Особливо на це слід звертати увагу при оснащенні навчальних кабінетів. Практика підтверджує, що у Новій українській школі використовується багато настінних плакатів, стендів, таблиць, дидактики, що кріпиться за допомогою магнітів. Усі ці сучасні навчальні засоби дуже яскраві, різнобарвні, з кольоровими малюнками - а отже при надмірному використанні створюють зворотний ефект. Замість того, щоб захопитися цікавою інформацією, учні будуть швидко втомлюватися, розпорошувати свою увагу й не зможуть концентруватися на навчальному процесі. Тому педагогічним працівникам та адміністраціям закладів освіти необхідно:

- використовувати у навчальних кабінетах змінні плакати, стенди, щоб не перевтомлювати дітей;

- не перезавантажувати освітнє середовище матеріалами, що не мають безпосередньої користі для навчального процесу й не стосуються затвердженої програми.

• у навчальних кабінетах упорядкувати освітні осередки для організації різних напрямів учнівської діяльності.

Висновки. Отже, упорядковане та організоване належним чином освітнє середовище закладу освіти є одним із важливим складником забезпечення надання якісних освітніх послуг та успішної реалізації ідей Нової української школи. Це важливо враховувати також при переході реформи на наступний рівень - базової середньої освіти.

\section{Лimepamypa:}

1. Сухомлинський В.О. Розмова з молодим директором / В.О.Сухомлинський. - К.: Радянська школа, 1988. - 284 с. С. 190-191.

2. Ясвин В.А. Образовательная среда: от моделирования к проектированию/ В.А. Ясвин. - М.: Смысл, 2001. - 365 с.

3. Нова українська школа [Електронний ресурс]. - Режим доступу: https://mon.gov.ua/ua/tag/nova-ukrainska-shkola .

4. Закон України Про повну загальну середню освіту [Електронний ресурс]. - Режим доступу: https://zakon.rada.gov.ua/laws/show/463-IX?fbclid=IwAR3H PX7nGuTO1v2MGt HJ 1p 0zWxrQUiuf7N07Ir3-KCwI-Ed2fpo9nbDPwRY\#Text.

5. Державні будівельні норми України. Будинки i споруди. Заклади освіти [Електронний ресурс]. - Режим доступу:https://www.minregion.gov.ua/wp-content/uploads /2018/06/V223_InBul.pdf .

6. Про затвердження Санітарного регламенту для закладів загальної середньої освіти [Електронний ресурс]. - Режим доступу:https://zakon.rada.gov.ua/laws/ show/z1111-20\#Text.

7. Проектування моделі нового освітнього середовища закладу загальної середньої освіти: Методичні рекомендації / автори-укладачі: Т.О.Кузьміч, Н.І.Мітяєва. - Херсон: КВН3 «Херсонська академія неперервної освіти», 2019 - 35 с.

8. Про затвердження методичних рекомендацій щодо організації освітнього простору Нової української школи [Електронний ресурс]. - Режим доступу: https://rada.info/upload/users_files/41912705/22b9942d83b1b05fbc 21ad7149e14731.pdf. 
9. Нова українська школа: порадник для вчителя / Під заг. ред. Бібік Н. М. - К.: ТОВ «Видавничий дім «Плеяди», 2017. - 206 с.

\section{References:}

1. Sukhomlynskyi V.O. (1988). Rozmova $z$ molodym dyrektorom [Conversation with a young director]. Kyiv: Radianska shkola [in Ukrainian].

2. Yasvyn V.A. (2001). Obrazovatelnaia sreda: ot modelyrovanyia $k$ proektyrovanyiu [Educational environment: from modeling to design]. Moscow: Smysl [in Russian].

3. Nova ukrainska shkola [New Ukrainian school]. (n.d.). mon.gov.ua. Retrieved from https://mon.gov.ua/ua/tag/nova-ukrainska-shkola [in Ukrainian].

4. Zakon Ukrainy Pro povnu zahalnu seredniu osvitu [The Law of Ukraine «On the full general average education»]. (n.d.). zakon.rada.gov.ua. Retrieved from https://zakon.rada.gov. ua/laws/show/463-IX?fbclid=IwAR3HPX7nGuTO1v2MGtHJ1p0zWxrQUiuf7N07Ir3-KCwIEd2fpo9nbDPwRY\#Text [in Ukrainian].

5. Derzhavni budivelni normy Ukrainy. Budynky i sporudy. Zaklady osvity [State building codes of Ukraine. Buildings and structures. Educational institutions]. (n.d.). www.minregion.gov.ua Retrieved from: https://www.minregion.gov.ua/wp-content/uploads /2018 /06/V223_InBul.pdf [in Ukrainian].

6. Pro zatverdzhennia Sanitarnoho rehlamentu dlia zakladiv zahalnoi serednoi osvity [On approval of the Sanitary Regulations for general secondary education institutions]. (n.d.). zakon.rada.gov.ua. Retrieved from https://zakon.rada.gov.ua/laws/ show/z1111-20\#Text [in Ukrainian].

7. Kuzmich T.O., Mitiaieva N.I. (Ed.). (2019). Proektuvannia modeli novoho osvitnoho seredovyshcha zakladu zahalnoi serednoi osvity: Metodychni rekomendatsii [Designing a model of a new educational environment of general secondary education: Guidelines]. Kherson: KVNZ «Khersonska akademiia neperervnoi osvity» [in Ukrainian].

8. Pro zatverdzhennia metodychnykh rekomendatsii shchodo orhanizatsii osvitnoho prostoru Novoi ukrainskoi shkoly [On approval of methodological recommendations for the organization of the educational space of the New Ukrainian School]. (n.d.). rada.info/upload/users_files. Retrieved from https://rada.info/upload/users_files/41912705/ 22b9942d83b1b05fbc 21ad7149 e14731.pdf [in Ukrainian].

9. Bibik N. M. (Ed.). (2017). Nova ukrainska shkola: poradnyk dlia vchytelia [New Ukrainian school: a guide for teachers]. Kyiv: TOV «Vydavnychyi dim «Pleiady» [in Ukrainian]. 